DOI: 10.20472/EFC.2019.012.022

\author{
VERONIKA SÍBRTOVÁ \\ University of Economics, Prague, Czech Republic \\ JANA TEPPEROVÁ \\ University of Economics, Prague, Czech Republic \\ JAN PAVEL \\ University of Econmics, Prague, Czech Republic
}

\title{
TAX FACTORS OF FOREIGN DIRECT INVESTMENTS FROM THE USA TO THE EU
}

\begin{abstract}
:
The main aim of the paper is to analyze which factors have an impact on the allocation of US FDIs in the EU countries. We use multivariable regression and OECD and Eurostat data, including also indicators of tax systems promoting and/or enabling the structures of aggressive tax planning. The results suggest that US FDIs are more widely placed in large and developed countries. Based on the analysis of the tax factors, the allocation of US FDIs in the EU are influenced by the effective corporate tax rate and the existence of the patent box regime or other preferential tax treatment of income from IP rights. Our control model of the relationship between the indicators of the tax system and the effective corporate tax rate shows that the effective corporate tax rate is influenced by the statutory corporate tax rate and three aggressive tax planning indicators other than the preferential tax treatment of income from IP rights.
\end{abstract}

\section{Keywords:}

FDI, Base Erosion, Profit Shifting, Tax Factors, Aggressive Tax Planning

JEL Classification: H25 


\section{Introduction}

Tax planning and international tax optimization by multinational entities (MNEs) are currently highly discussed topics. Tax avoidance directed through so-called offshore countries affects both developed and developing countries, which makes it a worldwide issue. According to the International Monetary Fund (2015), it is assumed that OECD countries lose USD 509,2 bn $(0,57 \%$ of GDP) and development countries USD 212,7 bn (1,7\% of GDP).

Tax avoidance by MNEs also raises the fundamental question of fairness of taxation and its sharing among tax jurisdictions. The distinction needs to be made between tax avoidance and tax evasion. Tax evasion being illegal activity when the tax is knowingly cut by, for example, misreporting taxable income/expenses. Tax evasion as a criminal act is part of the shadow economy and is measured by a so-called tax gap. Tax avoidance is more difficult to condemn, as it is carried out within the legal framework. The very undefined border is then between tax avoidance and aggressive tax avoidance. It can be said that some part of tax avoidance is accepted and even considered to be publicly beneficial, for example, investing in R\&D to lower the tax base. Some part of tax avoidance, mainly represented by the international tax schemes shifting taxable profits from high to low tax jurisdictions, is simply considered to be "too much". Managers of the MNEs argue in their defence that they have to account to the owners of the companies and thus need to keep the cost of the company (including tax) as low as possible (BBC, 2013). However, the arguments exist that such behaviour can be considered unethical (Lenz, 2018).

Foreign direct investments from the United States (US FDIs) represent the highest volumes, both inwards and outwards FDIs worldwide (UNCTAD, 2018). The most significant volume of outwards US FDIs directs to the Netherlands. This can be mainly due to the tax factors, as the Netherlands is so-called conduit country, e.g. country with the highest flow-through of FDls (e.g. Weyzig, 2013). Great Britain follows the Netherlands when it comes to the ration of FDIs to GDP. However, we are of the opinion that this is due to the extensive trading in between the two countries rather than Great Britain serving as the conduit country.

In 2015, based on the data from OECD database, US FDIs in the Netherlands reached USD 829,693 mio, which represents more than $60 \%$ of the total inwards FDIs into the Netherlands at the same year (USD 1,370,237 mio). Besides the Netherlands, an increasing trend in US FDIs is also in the following countries: Luxemburg, Ireland and Great Britain. Constant US FDIs are in Germany, France and Cyprus. In general, countries with an increasing volume of FDIs are developed and stable countries and often with the characteristics of the so-called conduit countries; this can be the trend for Netherlands, Luxemburg and Ireland (e.g. Weyzing, 2012, Haberly and Wójcik, 2014, Tepperová and Pavel, 2018).

At the macroeconomic level, base erosion and profit shifting by MNEs can manifest through the selected items of the Balance of Payments, primarily through the FDI data (e.g. OECD, 2015; UNCTAD, 2015, Tepperová and Pavel, 2018). Using FDI data, the size of the economy needs to be taken into consideration; OECD (2015) suggests the FDI to GDP ratio.

However, various factors influence the direction of FDIs. Parameters of the tax systems can be among such factors. European Commission (2015) provides the comparison of aggressive tax 
planning indicators among the EU countries and divides them into three groups. Indicators are marked as active if promoting tax planning structures, or passive, if making the tax planning structure possible but not promoting it by itself. Another category is the lack of anti-abuse when there are missing rules that could hinder aggressive tax planning as such.

This discussion paper aims to analyze the tax factors influencing US FDIs allocation in the EU countries. We use regression analysis to research these factors.

We structure the paper as follows. After this introduction, we describe data and methodology in section 2 . In section 3 , we present the regression model and its result, following with the standard testing of the model and control regression model for the effective corporate tax rate. We close the discussion paper with our conclusions in section 4.

This paper is based on the part of the diploma thesis by Síbrtová (2019) successfully defended at the University of Economics, Prague.

\section{Data and methodology}

We use multivariable regression to identify tax factors influencing US FDIs in the EU countries. Researchers have used a similar method in previous studies focused on variables affecting FDIs (e.g. Bénassy-Quéré, Fontagné and Lahréche-Révil, 2005, Haberly and Wójcik, 2014, Pavel and Tepperová, 2019).

\section{Data and variables}

Based on previous studies (e.g. Dunning, 1992, Blonigen, 2005, Mintz, 2006, Voget, 2014, Kersan-Škabić, 2015), we have identified possible determinants of FDIs, such as GDP, GDP per capita and effective corporate tax rate.

Moreover, we have considered, as possible variables influencing FDIs, the indicators of aggressive tax planning identified by the European Commission (2015). These represent specific tax rules within the tax systems of the EU countries. These indicators are included in the model as so-called dummy variables. If the indicator is present in the country, it reaches the value of 1 . On the contrary, the absence of such an indicator is included as 0 .

The dependent variable is the outflow of US FDIs, averaged for years 2010 to 2015 . We use the logarithm of these values to eliminate the high variability of the values for the countries of the EU.

Thus, independent variables are as follows:

- GDP,

- GDP per capita,

- effective corporate tax rate,

- thirty-three indicators of tax systems promoting and/or enabling the existence of the structures of aggressive tax planning.

We use 28 observations (for $28 \mathrm{EU}$ countries).

Data for US FDIs are from the OECD database (OECD, 2019), i.e. from the FDI statistics by partner country and by industry according to Benchmark Definition $4^{\text {th }}$ Edition (BMD4) for US FDIs 
for 2013 to 2015, and US FDIs for 2010 to 2012 are from the FDI statistics by partner country according to Benchmark Definition $3^{\text {rd }}$ Edition (BMD3). We use averaged values to eliminate annual fluctuations and calculate the averages from the data for 2010 to 2015. Further, data of US FDIs are in final model in log values.

Data for GDP and GDP per capita are from the OECD database as well. Data for GDP, representing the size of the economy, as well as for GDP per capita, representing the development of the economy, are in purchasing power parity for 2015. Data for both GDP and GDP per capita are in final model in log values to narrow the spread among the countries.

Data for effective average tax rates (EATR) are for 2015 and derived from the Eurostat database. Data for EATR are computed as a forward-looking micro-based method used Devereux/Griffith methodology ZEW (2018).

Indicators of tax systems promoting and/or enabling structures of aggressive tax planning are from the EC report (European Commission, 2015).

We present descriptive statistics of all the variables, except the dummies, in Table 1.

Table 1: Descriptive statistics of the variables

\begin{tabular}{lrrrrr}
\hline \multicolumn{1}{c}{ Variable } & Maximum & Minimum & Average & Median & $\begin{array}{c}\text { Standard } \\
\text { deviation }\end{array}$ \\
\hline US FDI & & & & & $1,78 \mathrm{e}+05$ \\
ln US FDI & $6,80 \mathrm{e}+05$ & 19,50 & 82788 & 6133,20 & 2,81 \\
GDP & 13,43 & 2,97 & 8,69 & 8,72 & $1,01 \mathrm{e}+06$ \\
ln GDP & $3,92 \mathrm{e}+06$ & 16085 & $7,05 \mathrm{e}+05$ & $2,99 \mathrm{e}+05$ & 1,46 \\
GDP per capita & 15,18 & 9,69 & 12,55 & 12,61 & 16941 \\
ln GDP per capita & $1,03 \mathrm{e}+05$ & 18186 & 38511 & 34378 & 0,37 \\
effective corporate tax rate & 11,54 & 9,81 & 10,49 & 10,45 & 6,91 \\
\hline
\end{tabular}

Source: own calculations based on OECD and Eurostat data

\section{Regression model and Results}

Based on above-mentioned studies and data availability, we specified the regression model estimated with the use of the least squares method as follows:

$$
\text { us } f d i=\alpha+\beta_{1} g d p+\beta_{2} g d p p c+\beta_{3} E T R+\delta_{i} I N D_{i}+\varepsilon
$$

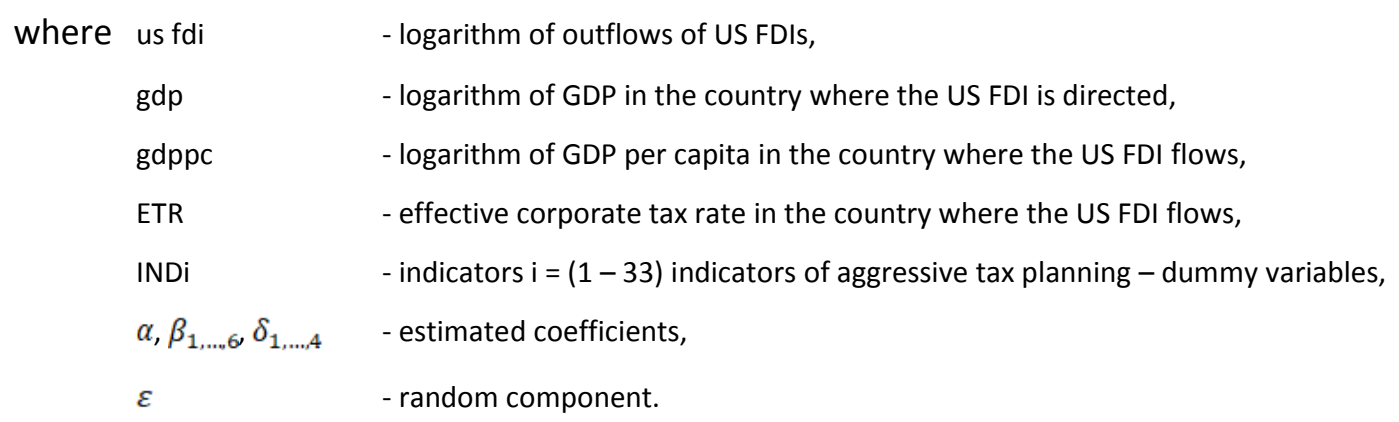


Results of the regression model are in Table 2.

Table 2: Regression model: OLS

Dependent variable: logarithm of US FDIs in the EU countries

\begin{tabular}{lccrll} 
& Coefficient & Standard Error & t-value & p-value & \\
\hline Constant & $-54,034$ & 4,799 & $-11,260$ & $<0,00001$ & $* * *$ \\
1_GDP & 1,215 & 0,123 & 9,857 & $<0,00001$ & $* * *$ \\
1_GDPpc & 4,664 & 0,464 & 10,060 & $<0,00001$ & $* * *$ \\
ETR & $-0,105$ & 0,032 & $-3,330$ & 0,0029 & $* * *$ \\
I17 & 2,179 & 0,395 & 5,519 & $<0,0001$ & $* * *$ \\
\hline Observations & \multicolumn{5}{c}{0.} \\
Coefficient of determination & 0,928 & \\
Adjusted coefficient of determination & 0,915 & \\
F (4, 23) & & 73,557 & \\
P-value (F) & & $<0,000001$ & \\
\hline
\end{tabular}

Note: $* \mathrm{p}<0,1 ; * * \mathrm{p}<0,05 ; * * * \mathrm{p}<0,01$

Source: own calculations

F-test for overall significance of regression suggests that the model is statistically significant. According to the adjusted regression coefficient, it explains more than $91 \%$ of the variability of outflows of US FDIs.

Results suggest that US FDls aims to larger economies, measured by the GDP, as well as to more developed economies, measured by the GDP per capita. 1\% increase in GDP per capita relates to $4,7 \%$ increase in US FDIs in the country.

The effective corporate tax rate also influences US FDIs. Increase in the effective corporate tax rate by 1 p.p. relates to a decrease in US FDls by more than $10 \%$.

Considering the tax indicators, indicator 17 (existence of patent box regime or other tax treatment of income from IP) resulted as statistically significant. The presence of this indicator increases US FDIs in the country. This indicator is, according to the European Commission (2015), an active one. This means that it promotes the formation of the ATP structures, as it provides tax favourable regimes for income from the IP rights.

We have further tested model for its reliability by making sure that the OLS model meets GaussMarkov assumptions. Especially, we have tested a set of following criteria: normality of residuals, collinearity among independent variables (VIF) and heteroscedasticity.

All the tests confirmed the reliability of the model.

Special attention needed to be devoted to the relation of the effective corporate tax rate variable and indicators of the tax systems. As the results suggest the indicator representing the preferential tax regime for income from the IP rights, we needed to eliminate potential collinearity between the effective corporate tax rate and this indicator. 
According to Morávková (2015), effective tax rates consider specific elements of the tax systems. These elements can also include some of the factors of aggressive tax planning as defined by the European Commission (2015). Thus, some of the indicators can influence the effective tax rate, which might detect collinearity between the effective tax rate and possible indicators in our regression model. This would undermine the reliability of the results. Even though the collinearity among the independent variable has not shown, we have further tested the relation between the effective tax rate and indicators of the tax systems, as identified by the European Commission (2015).

This control OLS regression model tested the relationship between effective corporate tax rate (dependent variable) and set of independent tax variables: the statutory tax rate and 33 indicators of tax systems. We have used the Eurostat database for both effective and statutory tax rates for 2015 to match the indicators specified in the European Commission report (2015).

Special attention was given to indicator 17 , due to its role in our main model. The positive relationship between the effective corporate tax rate and the indicator 17 was detected, meaning that the presence of this indicator in the EU country increases the effective corporate tax rate, which is against the economic theory. As this conclusion was not economically verified, indicator 17 cannot be considered as the one lowering/influencing the effective corporate tax rate.

Regression model assuming what factors influence the effective corporate tax rate identified as statistically significant: statutory corporate tax rate, and indicators 9 (tax deductions of interest is not dependent on its tax treatment in the country of creditor), 16 (notional tax deduction from share capital) and 30 (Unilateral ruling on, e.g. interest spread or royalty spread can be obtained).

Indicator 9 - tax deductions of interest is not dependent on its tax treatment in the country of creditor - represents the indicator of lack of anti-abuse rules. Tax deductibility of interest is not conditioned by taxation in the country of creditor, thus can lead to both non-taxation in one country and tax deductibility in the other and therefore can be used in the ATP structures. Indicator 16 - notional tax deduction from share capital - is a so-called active indicator. Some of the countries allow for a tax deduction of fictive interest from capital financing, which actively promotes ATP structures. Indicator 30 - unilateral ruling on, e.g. interest spread or royalty spread can be obtained - represent so-called passive indicator. Passive indicators give, according to the European Commission (2015), legal certainty to taxpayers and can confirm fictive flows of interests or royalties.

We present the results of the control model in Table 3.

\section{Table 3: Control regression model: OLS}

Dependent variable: Effective Corporate Tax Rate

\begin{tabular}{llcrll} 
& Coefficient & Standard Error & t-value & p-value & \\
\hline Constant & 1,763 & 0,912 & 1,932 & 0,017 & $*$ \\
Statutory tax rate & 0,943 & 0,032 & 29,740 & $<0,00001$ & $* * *$ \\
I9 & $-2,501$ & 0,981 & $-2,549$ & 0,018 & $* *$ \\
I16 & $-2,324$ & 0,941 & $-2,469$ & 0,021 & $* *$
\end{tabular}




\begin{tabular}{|c|c|c|c|}
\hline$-1,205$ & 0,546 & $-2,206$ & $* *$ \\
\hline Observations & & 28 & \\
\hline Coefficient of Determination & & 0,952 & \\
\hline Adjusted Coefficient of Determination & & 0,944 & \\
\hline $\mathrm{F}(4,23)$ & & 296,045 & \\
\hline P-value (F) & & $<0,000001$ & \\
\hline
\end{tabular}

Note: $* \mathrm{p}<0,1 ; * * \mathrm{p}<0,05 ; * * * \mathrm{p}<0,01$

Source: own calculations

F-test for overall significance of regression suggests that the model is statistically significant, and according to the adjusted coefficient of determination, it explains more than $94 \%$ of the variability of the effective corporate tax rate. According to our assumption and not surprisingly, the effective corporate tax rate is positively dependent on the statutory corporate tax rate. Results further show that the presence of indicators 9,16 or 30 , as described above, leads to a decrease in the effective tax rate.

We have tested the control model for collinearity among the variables, which was not confirmed.

\section{Conclusions}

Aggressive tax planning is one of the main issues to be solved by the international organization, such as OECD and European Commission.

OECD has published 15 reports on base erosion and profit shifting (BEPS) in 2015. In the final report for action 11, OECD (2015) identified six possible indicators that can reveal the presence of base erosion and profit shifting. One of such indicators are FDIs and its abnormal inflows or outflows.

Among the EU countries, those further stated report abnormal values of FDIs to GDP: Luxemburg, Netherland and Great Britain. At the same time, amounts of both inflows and outflows of US FDls are the most significant worldwide (UNCTAD, 2018).

Our analysis showed that among the factors influencing the allocation of US FDIs in the EU countries belong: the size of the economy measured by GDP, development of the economy measured by GDP per capita, effective corporate tax rate and the existence of the patent box regime or other tax treatment of the income from the IP rights.

Other indicators of the tax system proved to decrease the effective corporate tax rate. Besides the statutory tax rate that is the significant variable to influence the effective tax rate, the presence of three indicators of aggressive tax planning decrease the effective corporate tax rate as well. These are following indicators: tax deductions of interest are not dependent on its tax treatment in the country of creditor, notional tax deduction from share capital and unilateral ruling on, e.g. interest spread or royalty spread can be obtained.

According to OECD (2018), FDIs decreased by $35 \%$ in the first half of 2018 compared to the second half of 2017. This might be, according to the report, due to the US tax reform, which lowered the statutory tax rate for corporations from $35 \%$ to $21 \%$. Profit repatriation from daughter to parent company lead to negative flows of reinvested profits. US FDIs to the OECD countries decreased by $36 \%$ and outflows of FDls decreased by $65 \%$. 
Countries search for new rules to hinder tax optimization by MNEs. Leading platforms for bringing the solutions and putting it in practice are OECD and the European Commission. Among the 15 BEPS reports by OECD (2015) addressing issues of tax avoidance by MNEs, four were adopted as the so-called minimum standard. These are Action 5 - Harmful practices, Action 6 - Treaty abuse, Action 13 TP documentation, Country by country reporting and Action 14 - Dispute resolution. One hundred twenty-nine countries agreed to so-called Inclusive Framework of BEPS, meaning those countries have committed to implement at least these minimum standards.

European Commission has issued two anti-tax avoiding directives (COUNCIL DIRECTIVE (EU) 2016/1164 - ATAD and Council Directive (EU) 2017/952 of 29 May 2017 amending Directive (EU) 2016/1164 - ATAD II) based on which the EU countries are obliged to implement measures against tax optimization by MNEs to its national legislation, namely new rules on interests deduction, hybrid mismatches, control foreign company (CFC) rules, exit tax and general anti-tax avoidance rule (GAAR).

At the same time, countries try to find consensus on the new functional system on taxation of the digital economy. Both long-term and interim solutions are discussed. Some countries take unilateral measures in variations of digital service tax.

All those measures significantly influence the international tax environment and change the playing field for the tax optimization by MNEs. Further research can show how effective these measures are and how they influence the FDI flows.

\section{Acknowledgements}

The article is an output of a research project "Fair corporate taxation: Measurement of the impact of the corporate profit shifting on the budget of the Czech Republic" registered by the Czech Science Foundation under the registration number 18-14082S.

\section{References}

BÉNASSY-QUÉRÉ, A., FONTAGNÉ, L. and LAHRÉCHE-RÉVIL, A. (2005) How Does FDI React to Corporate Taxation? International Tax and Public Finance, 12, 583-603. Springer

Science + Business Media, Inc. Printed in the Netherlands [online] [cit.30-4-2019] Available at: https://link.springer.com/article/10.1007/s10797-005-2652-4

BBC (2013) UK v Google - Paying the right Taxation. [online] [cit.22-6-2019] Available at: https://www.youtube.com/watch?v=B9-BZ4TeAg0

BLONIGEN, B. A. (2005) A Review of the Empirical Literature on FDI Determinants. National Bureau of Economic Research Working Paper 11299. [online] [cit-10-4-2019] Available at: https://www.researchgate.net/publication/5144176_A_Review_of_Empirical_Lite rature_on_FDI_Determinants

DUNNING, J. H. (1992) Trade, Location and Economic Activity and the Multinational Enterprise:

A Search for Eclectic Approach. New York: Routledge. Theory of Transnational Corporation, s. 183-218. 
EUROPEAN COMMISSION (2015) Study on Structures of Aggressive Tax Planning and Indicators. Final Report. Working paper no. 61/2015. ISSN 1725-7565. [online] [cit. 15-62019] Available at:

https://ec.europa.eu/taxation_customs/sites/taxation/files/resources/documents/taxation/gen _info/economic_analysis/tax_papers/taxation_paper_61.pdf

EUROPEAN COMMISSION (2016) Taxation Trends in the European Union (2016) Table 85:

Effective average corporate tax rates. Available at:

https://ec.europa.eu/taxation_customs/sites/taxation/files/resources/documents/taxation/gen info/economic_analysis/tax_structures/2016/econ_analysis_report_2016.pdfHABERLY, D. a WÓJCIK, D. (2014) Tax havens and the production of offshore FDI: an empirical analysis. Journal of Economic Geography, no. 15, s. 75-101. DOI: 10.1093/jeg/lbu003. [online] [cit. 25-2-2019] Available at: https://papers.ssrn.com/sol3/papers.cfm?abstract_id=2252431

INTERNATIONAL MONETARY FUND (2015) IMF: developing countries‘ BEPS revenue losses exceed \$200 billion. [online] [cit-15-06-2019] Available at:

http://uncounted.org/2015/06/01/imf-developing-countries-beps-revenue-losses-exceed200-billion/

KERSAN-ŠKABIĆ, I. (2015) The Importance of Corporate Taxation for FDI Attractiveness of Southeast European Countries. Panoeconomicus, vol. 62, s. 105-122. doi: 10.2298/PAN1501 105K. [online] [cit.10-03-2019] Available at: https://search.proquest.com/docview/1674425392/fulltextpdf/b0b6405da37045 5epq/1 ?accountid=17203

LENZ, H. (2018) Aggressive Tax Avoidance by Managers of Multinational Companies as a Violation of Their Moral Duty to Obey the Law: A Kantian Rationale. Journal of Business Ethics, December 2018. [online] [cit. 22-06-2019] Available at: https://link.springer.com/article/10.1007/s10551-018-4087-8

MINTZ, J. M. (2006) The Changing Structure of Tax Policies for Foreign Direct Investment in Developing Countries. New York: Springer. The Challenges of Tax Reform in a Global Economy, s. 155-166. [online] [cit.20-06-2019] Available at: https://www.issuelab.org/resources/5252/5252.pdf 
MORÁVKOVÁ, J. (2015) Efektivní sazba korporátní daně. Český finanční a účetní časopis, 2015, roč. 10, č. 4, s. 39-58. [online] [cit.15-06-2019] Available at:

https://www.google.com/url?sa=t\&rct=j\&q=\&esrc=s\&source=web\&cd=1\&ved=2ahUKEwjgjv WNtvfhAhU08uAKHWMjC30QFjAAegQIBBAC\&url=https\%3A\%2F\%2Fwww.vse.cz\%2Fpole k\%2Fdownload.php\%3Fjnl\%3Dcfuc\%26pdf\%3D458.pdf\&usg=AOvVaw1BQE9EFKLvmgNC AS2DQ2VS

OECD (2015) Measuring and Monitoring BEPS, Action 11-2015 Final Report. [online] [cit.15-062018] Available at: http://www.oecd.org/tax/measuring-and-monitoring-beps-action-112015-final-report-9789264241343-en.htm

OECD (2018) FDI in Figures. [online] [cit-15-06-2019] Available at: http://www.oecd.org/investment/FDI-in-Figures-October-2018.pdf OECD (2019) FDI statistics. OECD database. Available at: https://stats.oecd.org/index.aspx?DataSetCode=FDI_FLOW_PARTNER

PAVEL, J. and TEPPEROVÁ, J. (2019) FDI and Base erosion and profit shifting from the Czech Republic. Theoretical and Practical Aspects of Public Finance 2019, presented at the conference at $12^{\text {th }}$ and $13^{\text {th }}$ April 2019. University of Economics, Prague.

SíBRTOVÁ, V. (2019) Daňové faktory ovlivňující alokaci PZI z USA v EU. Diploma thesis, University of Economics, Prague.

TEPPEROVÁ, J. and PAVEL, J. (2018) Aggressive tax planning and Balance of Payments public data. Proceedings of the 23rd International Conference - Theoretical and Practical Aspects of Public Finance 2018. Praha: Oeconomica. University of Economics, Prague, s. 153-158. [online] [cit.10-06-2019] Available at: https://kvf.vse.cz/wpcontent/uploads/page/158/TPAVF-Sborn\%C3\%ADk-2018_FINAL-last.pdf

UNCTAD (2018) World Investment Report 2018, Key messages and overview. [online] [cit.15-042019] Available at: https://unctad.org/en/PublicationsLibrary/wir2018_overview_en.pdf VOGET, J. (2014) The effect of taxes on foreign direct investment: a survey of the empirical evidence. European Tax Policy Forum, Policy Paper 3. [online] [cit-09-03-2019] Available at: http://www.etpf.org/papers/PP003FDI.pdf

WEYZIG, F. (2013) Tax treaty shopping: structural determinants of Foreign Direct Investment routed through the Netherlands. International Tax and Public Finance. Springer; International Institute of Public Finance, vol. 20(6), pages 910-937, December.

ZEW (2018) Effective Tax Levels using the Devereux/Griffith Methodology. Final Report 2018. Project for the EU Commission TAXUD/2013/CC/120. 